\title{
Infection Status with Digenetic Trematode Metacercariae in Fishes from Coastal Lakes in Gangwon-do, Republic of Korea
}

\author{
Woon-Mok Sohn ${ }^{1, *}$, Byoung-Kuk Na', Shin-Hyeong $\mathrm{Cho}^{2}$, Soon-Won Lee ${ }^{3}$ \\ ${ }^{1}$ Department of Parasitology and Tropical Medicine, and Institute of Health Sciences, Gyeongsang National University College of Medicine, \\ Jinju 52727, Korea; 'Division of Vectors and Parasitic Diseases, Centers for Disease Control and Prevention, Osong 28159, Korea; \\ ${ }^{3}$ Infection Disease Intelligence Division, Gangwon Institute of Health and Environment, Chuncheon 24203, Korea
}

\begin{abstract}
The infection status of digenetic trematode metacercariae (DTM) was investigated in fishes from coastal lakes in Gangwon-do, the Republic of Korea (Korea). All fishes collected in 5 lakes were examined with the artificial digestion method. More than 10 species, i.e., Metagonimus spp., Pygidiopsis summa, Centrocestus armatus, Metorchis orientalis, M. taiwanensis, Clinostomum complanatum, Echinostoma spp., Stictodora spp., Diplostomum sp. and Diplostomid No. 1. by Morita (1960), of DTM were detected in fishes from 5 coastal lakes in Gangwon-do. Metagonimus spp. metacercariae were found in 52 (41.3\%) out of 126 sea rundace, Tribolodon hakonensis, from 5 lakes, and their density was 14.6 per fish infected. P. summa metacercariae were detected in $48(84.2 \%)$ out of 57 mullets from 5 lakes, and their density was 316 per fish infected. C. armatus metacercariae were detected in 7 (14.6\%) T. hakonensis and 3 (15.0\%) Tridentiger brevispinis from Hyang-ho, and 5 (19.2\%) Acanthogobius flavimanus from Gyeongpo-ho. Stictodora spp. metacercariae were found in 4 fish species, i.e., Tridentiger obscurus, Tridentiger trigonocephalus, Chelon haematocheilus, and Acanthogobius lactipes, from Gyeongpo-ho. Total 15 C. complanatum metacercariae were detected in $2(9.1 \%)$ crucian carp, Carassius auratus, from Songji-ho. $M$. taiwanensis metacercariae were found in T. hakonensis from Hyang-ho and Gyeongpo-ho and in Pseudorasbora parva from Gyeongpo-ho. Total $11 \mathrm{M}$. orientalis metacercariae were detected in $3(6.3 \%)$ T. hakonensis from Hyang-ho. From the above results, it was confirmed that various species of DTM are infected in fishes from coastal lakes in Gangwon-do, Korea.
\end{abstract}

Key words: Metagonimus spp., Pygidiopsis summa, Centrocestus armatus, Clinostomum complanatum, digenetic trematode, metacercariae, coastal lake, Gangwon-do

\section{INTRODUCTION}

Digenetic trematode (subclass Digenea) is a relatively larger group and generally has 3 hosts, 2 intermediates and 1 definitive, in its life history. Members in some animal groups, i.e., fish, amphibian, reptilian, mollusc and arthropod, serve as the second intermediate hosts. They have the infective stage larvae, metacercariae, and act as the source of infection in the definitive hosts including humans [1]. It has been known that fish is the most susceptible host, which is frequently infected with various species of digenetic trematode metacercariae (DTM),

- Received 18 October 2019, revised 21 November 2019, accepted 28 November 2019.

*Corresponding author (wmsohn@gnu.ac.kr)

(c) 2019, Korean Society for Parasitology and Tropical Medicine

This is an Open Access article distributed under the terms of the Creative Commons Attribution Non-Commercial License (http://creativecommons.org/licenses/by-nc/4.0) which permits unrestricted non-commercial use, distribution, and reproduction in any medium, provided the original work is properly cited. and each species of DTM are morphologically distinguishable with their characteristic features and components [2,3].

Nowadays, infections with fishborne zoonotic trematodes (FZT) including clonorchiasis is to be the most important parasitic diseases in the Republic of Korea (Korea) [4-7]. A team of Korean CDCP (Centers for Disease Control and Prevention) has performed the control project for zoonotic trematodiases in the adjacent residents of 5 major rivers, i.e., Nakdong-gang (gang means river), Seomjin-gang, Geum-gang, Yeongsangang and Han-gang, in Korea [6,7]. The team also participated in the surveys on the infection status of infective stage (metacercariae: infection sources) of $\mathrm{ZT}$ in fishes from water systems of major rivers in Korea [8-12].

In Korea, some workers surveyed the infection status with DTM in fishes from various local sites [13-22]. Chun [13] detected several species of DTM in fishes from Nakdong-gang. Lee [14] and Hwang and Choi [15] investigated the infection 
status of DTM in fishes from Geumho-gang (a branch of Nakdong-gang) in Gyeongsangbuk-do (do=Province). Rhee et al. $[16,17]$ examined the infection status of DTM in fishes from Mangyeong-gang and Dongiin-gang in Jeollabuk-do. Joo [18] surveyed the changing pattern of DTM infection in fishes from Taewha-gang in Gyeongsangnam-do. Kong et al. [19] investigated the infection status of DTM in fishes from Miryanggang in Gyeongsangnam-do. Sohn and Choi [20] surveyed the infection status of DTM in fishes from Junam-jeosuji (jeosuji means reservoir) in Gyeongsangnam-do. Recently, Sohn et al. [21] reported the infection status of DTM in freshwater fishes from water systems of Hantan-gang and Imjin-gang, and Sohn and $\mathrm{Na}$ [22] also reported the infection status of DTM in freshwater fishes from 2 representative visiting sites, Junam-jeosuji and Woopo-neup (neup means swamp), of migratory birds in Gyeongsangnam-do, Korea. However, most of previous studies were performed with fishes from streams and rivers except for Sohn and Choi [20] and Sohn and $\mathrm{Na}$ [22], and from the southern regions except for Sohn et al. [21]. Furthermore, infection status with DTM in fishes from coastal lakes in Gangwon-do have not been surveyed yet. Therefore, we are going to investigate the infection status of DTM in fishes from 5 coastal lakes, i,e., Hwajinpo-ho (ho means lake), Songji-ho, Mae-ho, Hyang-ho and Gyeongpo-ho, in Gangwon-do.

\section{MATERIALS AND METHODS}

\section{Collection sites of Fish}

Fish collection sites were as follows: Hwajinpo-ho in Geojineup (eup= town) (latitude: 38.466792; longitude: 128.442357), Goseong-gun (gun=county); Songi-ho in Jukwang-myeon (myeon = township) $(38.335426 ; 128.51339)$, Goseong-gun; Mae-ho in Hyeonnam-myeon (37.949674; 128.774899), Yangyang-gun; Hyang-ho in Jumunjin-eup (37.912322; 128.812649), Gangneung-si; Gyeongpo-ho in Woonjeong-dong (37.797481; 128.911507), Gangneung-si, Gangwon-do.

\section{Fishes examined by the coastal lakes}

Total 92 fishes (11 species) from Hwajinpo-ho were examined in 2014 and 2017. Fish species (No. of fish) examined were Acanthogobius flavimanus (23) Konosirus punctatus (12), Mugil cephalus (13), Carassius auratus (10), Acanthogobius lactipes (7), Cyprinus carpio (2), Tribolodon hakonensis (9), Favonigobius gymnauchen (9), Tridentiger brevispinis (4), Tridentiger trigonocephalus (2), Silurus asotus (1). A total of 113 fishes (9 spp.) from Songji-ho were examined in 2015 and 2017. Fish species (No. of fish) examined were T. hakonensis (33), C. auratus (22), A. flavimanus (11), M. cephalus (11), T. brevispinis (10), A. lactipes (10), Gymnogobius castaneus (10), K. punctatus (5), Chelon haematocheilus (1).

Total 74 fishes (9 spp.) from Mae-ho were examined in 2017. Fish species (No. of fish) examined were A. flavimanus (16), T. hakonensis (12), T. brevispinis (10), G. castaneus (10), A. lactipes (9), C. auratus (7), K. punctatus (5), M. cephalus (3), C. haematocheilus (2). A total of 155 fishes (11 spp.) from Hyangho were examined in 2015 and 2017. Fish species (No. of fish) examined were T. hakonensis (48), G. castaneus (21), T. brevispinis (20), C. auratus (19), Hypomesus nipponensis (15), A. lactipes (14), M. cephalus (5), K. punctatus (9), Plecoglossus altivelis (2), C. haematocheilus (1), C. capio (1). Total 151 fishes (13 spp.) from Gyeongpo-ho were examined in 2014 and 2017. Fish species (No. of fish) examined were A. flavimanus (26), T. hakonensis (24), K. punctatus (20), M. cephalus (15), Acanthopagrus schlegeli (15), C. auratus (10), Tridentiger obscurus (10), T. trigonocephalus (9), C. haematocheilus (6), F. gymnauchen (6), Pseudorasbora parva (5), C. capio (3), A. lactipes (2).

\section{Examination methods}

All collected fishes with ice were transferred to the laboratory of the Department of Parasitology and Tropical Medicine, Gyeongsang National University College of Medicine, Jinju, Korea. After the identification of fish species, they were individually ground with a mortar. Each ground fish meat was mixed with artificial gastric juice and the mixture was incubated at $36^{\circ} \mathrm{C}$ for about $2 \mathrm{hr}$. The digested material was filtered with $1 \times 1 \mathrm{~mm}$ of mesh, and washed with $0.85 \%$ saline untill vthe supernatant is clear. The sediment was carefully examined under a stereomicroscope. Digenetic trematode metacercariae (DTM) except for 3 species, i.e., Metacercaria hasegawai, Exorchis oviformis and Pseudoexorchis major, were separately collected by the general feature [2,3], and they were counted to get hold of infection rates (\%) and intensities (No. of DTM per fish infected) by fish species.

\section{RESULTS}

\section{Infection status of DTM in fishes from 5 coastal lakes in Gangwon-do}

In fishes from Hwajinpo-ho, 4 species, i.e., Metagonimus spp., Pygidiopsis summa, Metorchis orientalis and Diplostomid 
No. 1. by Morita (1960) [23], of DTM were detected, and their infection status by the fish species is detailedly designated in Table 1. Total 6 species, i.e., Metagonimus spp., P. summa, Echi- nostoma sp., Clinostomum complanatum, Diplostomum sp. and Diplostomid No. 1. by Morita (1960), of DTM were found in fishes from Songii-ho, and their infection status by the fish

Table 1. Infection status of trematode metacercariae by fish species caught from Hwajinpo-ho (Lake) in Goseong-gun, Gangwon-do, Korea

\begin{tabular}{lccc}
\hline $\begin{array}{l}\text { Trematode } \\
\text { Fish sp. infected }\end{array}$ & No. of fish examined & No. (\%) of fish infected & \multicolumn{2}{c}{ No. of metacercariae detected } \\
\cline { 3 - 4 } $\begin{array}{l}\text { Metagonimus spp. } \\
\quad \text { Tribolodon hakonensis }\end{array}$ & 9 & $1(11.1)$ & Range \\
$\begin{array}{l}\text { Pygidiopsis summage } \\
\text { Mugil cephalus }\end{array}$ & & & \\
Metorchis orientalis & 13 & $9(69.2)$ & $2-3,050$ \\
$\quad$ Tribolodon hakonensis & 9 & $1(11.1)$ & - \\
$\begin{array}{l}\text { Diplostomid No. 1. larva by Morita (1960) } \\
\text { Acanthogobius flavimanus }\end{array}$ & 23 & $3(13.0)$ & 1.0 \\
$\quad \begin{array}{l}\text { Tribolodon hakonensis } \\
\text { Subtotal }\end{array}$ & 9 & $9(100)$ & $1-2$ \\
\hline
\end{tabular}

aPreviously reported in Sohn et al. [29].

Table 2. Infection status of trematode metacercariae by fish species caught from Songji-ho (Lake) in Goseong-gun, Gangwon-do, Korea

\begin{tabular}{|c|c|c|c|c|}
\hline \multirow{2}{*}{$\begin{array}{l}\text { Trematode } \\
\text { Fish sp. infected }\end{array}$} & \multirow{2}{*}{ No. of fish examined } & \multirow{2}{*}{ No. (\%) of fish infected } & \multicolumn{2}{|c|}{ No. of metacercariae detected } \\
\hline & & & Range & Average \\
\hline $\begin{array}{l}\text { Metagonimus spp. } \\
\text { Tribolodon hakonensis }\end{array}$ & 33 & $2(6.1)$ & $1-2$ & 1.5 \\
\hline $\begin{array}{l}\text { Pygidiopsis summa } \\
\text { Mugil cephalus } \\
\text { Chelon haematocheilus } \\
\text { Subtotal }\end{array}$ & $\begin{array}{r}11 \\
1 \\
12\end{array}$ & $\begin{array}{r}11(100) \\
1(100) \\
12(100)\end{array}$ & $\begin{array}{l}32-678 \\
- \\
32-678\end{array}$ & $\begin{array}{l}147.0 \\
117.0 \\
144.0\end{array}$ \\
\hline $\begin{array}{l}\text { Echinostoma sp. } \\
\text { Tribolodon hakonensis }\end{array}$ & 33 & $1(3.0)$ & - & 1.0 \\
\hline $\begin{array}{l}\text { Clinostomum complanatum } \\
\text { Carassius auratus }\end{array}$ & 22 & $2(9.1)$ & $2-13$ & 7.5 \\
\hline $\begin{array}{l}\text { Diplostomid No. 1. larva by Morita (1960) } \\
\text { Tribolodon hakonensis }\end{array}$ & 33 & $10(30.3)$ & $1-7$ & 2.5 \\
\hline $\begin{array}{l}\text { Diplostomum sp. } \\
\text { Tribolodon hakonensis }\end{array}$ & 33 & $5(15.2)$ & $1-2$ & 1.2 \\
\hline
\end{tabular}

aPreviously reported in Sohn et al. [29].

Table 3. Infection status of trematode metacercariae by fish species caught from Mae-ho (Lake) in Yangyang-gun, Gangwon-do, Korea

\begin{tabular}{|c|c|c|c|c|}
\hline \multirow{2}{*}{$\begin{array}{l}\text { Trematode } \\
\text { Fish sp. infected }\end{array}$} & \multirow{2}{*}{ No. of fish examined } & \multirow{2}{*}{ No. (\%) of fish infected } & \multicolumn{2}{|c|}{ No. of metacercariae detected } \\
\hline & & & Range & Average \\
\hline $\begin{array}{l}\text { Metagonimus spp. } \\
\text { Tribolodon hakonensis }\end{array}$ & 12 & $4(33.3)$ & $1-29$ & 11 \\
\hline $\begin{array}{l}\text { Pygidiopsis summa } \\
\text { Mugil cephalus } \\
\text { Chelon haematocheilus } \\
\text { Subtotal }\end{array}$ & $\begin{array}{l}3 \\
2 \\
5\end{array}$ & $\begin{array}{l}2(66.7) \\
2(100) \\
4(80.0)\end{array}$ & $\begin{array}{c}- \\
- \\
1-3\end{array}$ & $\begin{array}{l}3 \\
1 \\
2\end{array}$ \\
\hline $\begin{array}{l}\text { Echinostoma sp. } \\
\text { Acanthogobius lactipes }\end{array}$ & 9 & $1(11.1)$ & - & 1 \\
\hline $\begin{array}{l}\text { Diplostomum sp. } \\
\text { Tribolodon hakonensis }\end{array}$ & 12 & $1(8.3)$ & - & 1 \\
\hline
\end{tabular}


Table 4. Infection status of trematode metacercariae by fish species caught from Hyang-ho (Lake) in Gangneung-si, Gangwon-do, Korea

\begin{tabular}{|c|c|c|c|c|}
\hline \multirow{2}{*}{$\begin{array}{l}\text { Trematode } \\
\text { Fish sp. infected }\end{array}$} & \multirow{2}{*}{ No. of fish examined } & \multirow{2}{*}{ No. (\%) of fish infected } & \multicolumn{2}{|c|}{ No. of metacercariae detected } \\
\hline & & & Range & Average \\
\hline $\begin{array}{l}\text { Metagonimus spp. } \\
\text { Tribolodon hakonensis }\end{array}$ & 48 & $31(64.6)$ & $1-92$ & 18.3 \\
\hline $\begin{array}{l}\text { Pygidiopsis summa } \\
\text { Mugil cephalus } \\
\text { Chelon haematocheilus } \\
\text { Subtotal }\end{array}$ & $\begin{array}{l}5 \\
1 \\
6\end{array}$ & $\begin{array}{l}1(20.0) \\
1(100) \\
2(33.3)\end{array}$ & $\begin{array}{l}- \\
- \\
1-227\end{array}$ & $\begin{array}{r}1.0 \\
227.0 \\
114.0\end{array}$ \\
\hline $\begin{array}{l}\text { Centrocestus armatus } \\
\text { Tribolodon hakonensis } \\
\text { Tridentiger brevispinis } \\
\text { Subtotal }\end{array}$ & $\begin{array}{l}48 \\
20 \\
68\end{array}$ & $\begin{array}{r}7(14.6) \\
3(15.0) \\
10(14.7)\end{array}$ & $\begin{array}{l}1-7 \\
1-18 \\
1-18\end{array}$ & $\begin{array}{l}2.1 \\
7.3 \\
3.7\end{array}$ \\
\hline $\begin{array}{l}\text { Metorchis orientalis } \\
\text { Tribolodon hakonensis }\end{array}$ & 48 & $3(6.3)$ & $1-9$ & 3.7 \\
\hline $\begin{array}{l}\text { Metorchis taiwanensis } \\
\text { Tribolodon hakonensis }\end{array}$ & 48 & $10(20.8)$ & $1-17$ & 5.2 \\
\hline $\begin{array}{l}\text { Echinostoma sp. } \\
\text { Tribolodon hakonensis }\end{array}$ & 48 & $2(4.2)$ & - & 1.0 \\
\hline $\begin{array}{l}\text { Diplostomum sp. } \\
\text { Tribolodon hakonensis }\end{array}$ & 48 & $4(8.3)$ & $1-5$ & 2.0 \\
\hline $\begin{array}{l}\text { Diplostomid No. 1. larva by Morita (1960) } \\
\text { Tribolodon hakonensis }\end{array}$ & 48 & $1(2.1)$ & - & 2.0 \\
\hline
\end{tabular}

Table 5. Infection status of trematode metacercariae by fish species from Gyeongpo-ho (Lake) in Gangneung-si, Gangwon-do, Korea

\begin{tabular}{|c|c|c|c|c|}
\hline \multirow{2}{*}{$\begin{array}{l}\text { Trematode } \\
\text { Fish sp. infected }\end{array}$} & \multirow{2}{*}{ No. of fish examined } & \multirow{2}{*}{ No. (\%) of fish infected } & \multicolumn{2}{|c|}{ No. of metacercariae detected } \\
\hline & & & Range & Average \\
\hline \multicolumn{5}{|l|}{ Metagonimus spp. } \\
\hline Tribolodon hakonensis & 24 & 14 (58.3) & $1-38$ & 10.1 \\
\hline Acanthopagrus schlegeli & 15 & $1(6.7)$ & - & 1.0 \\
\hline Mugil cephalus & 15 & $1(6.7)$ & - & 1.0 \\
\hline Subtotal & 54 & $16(29.6)$ & $1-38$ & 9.0 \\
\hline \multicolumn{5}{|l|}{ Pygidiopsis summa } \\
\hline Mugil cephalus & 15 & $15(100)$ & $82-1,286$ & 309.0 \\
\hline Chelon haematocheilus ${ }^{a}$ & 6 & $6(100)$ & $167-918$ & 419.0 \\
\hline Subtotal & 21 & $21(100)$ & $82-918$ & 341.0 \\
\hline \multicolumn{5}{|l|}{ Centrocestus armatus } \\
\hline Acanthogobius flavimanus & 26 & $5(19.2)$ & $1-6$ & 3.0 \\
\hline \multicolumn{5}{|l|}{ Metorchis taiwanensis } \\
\hline Tribolodon hakonensis & 24 & $2(8.3$ & $1-6$ & 3.5 \\
\hline Pseudorasbora parva & 5 & $1(20.0)$ & - & 1.0 \\
\hline Subtotal & 29 & $3(10.3)$ & $1-6$ & 2.7 \\
\hline \multicolumn{5}{|l|}{ Echinostoma spp. } \\
\hline Tridentiger obscurus & 10 & $1(10.0)$ & - & 1.0 \\
\hline Tridentiger trigonocephalus & 9 & $1(11.1)$ & - & 1.0 \\
\hline Pseudorasbora parva & 5 & $2(40.0)$ & $3-12$ & 7.5 \\
\hline Subtotal & 24 & $4(16.7)$ & $1-12$ & 4.3 \\
\hline \multicolumn{5}{|l|}{ Stictodora spp. } \\
\hline Tridentiger obscurus & 10 & $9(90.0)$ & $1-20$ & 6.4 \\
\hline Tridentiger trigonocephalus & 9 & $1(11.1)$ & - & 1.0 \\
\hline Chelon haematocheilus & 6 & $2(33.3)$ & $6-7$ & 6.5 \\
\hline Acanthogobius lactipes & 2 & $1(50.0)$ & - & 1.0 \\
\hline Subtotal & 27 & $13(48.2)$ & $1-20$ & 5.6 \\
\hline \multicolumn{5}{|l|}{ Diplostomum sp. } \\
\hline Pseudorasbora parva & 5 & $1(20.0)$ & - & 2.0 \\
\hline
\end{tabular}

aPreviously reported in Sohn et al. [29]. 
species is detailedly revealed in Table 2.

In fishes from Mae-ho, 4 species, i.e., Metagonimus spp., $P$. summa, Echinostoma sp., and Diplostomum sp., of DTM were detected, and their infection status by the fish species is detailedly shown in Table 3. Total 8 species, i.e., Metagonimus spp., $P$. summa, Centrocestus armatus, M. orientalis, Metorchis taiwanensis, Echinostoma sp., Diplostomum sp. and Diplostomid No. 1. by Morita (1960), of DTM were found in fishes from Hyang-ho, and their infection status by the fish species is detailedly designated in Table 4. In fishes from Gyeongpo-ho, total 7 species, i.e., Metagonimus spp., P. summa, C. armatus, M. taiwanensis, Echinostoma sp., Stictodora spp. and Diplostomum sp., of DTM were detected, and their infection status by the fish species is detailedly revealed in Table 5 .

\section{Infection status with ZTM in fishes from 5 coastal lakes in Gangwon-do}

The metacercariae of Metagonimus spp. (MtMc) were found in 52 (41.3\%) out of 126 sea rundace, T. hakonensis, from 5 lakes, and their intensity was 14.6 per fish infected. The detail infection status with MtMc by the survey localities is revealed in Table 6. P. summa metacercariae (PsMc) were detected in 48 (84.2\%) out of 57 mullets from 5 lakes, and their intensity was 316 per fish infected. The detail infection status with PsMc by the survey localities is designated in Table 7 .
The metacercariae of C. armatus were detected in 7 (14.6\%) T. hakonensis and $3(15.0 \%)$ T. brevispinis from Hyang-ho, and 5 (19.2\%) A. flavimanus from Gyeongpo-ho. Stictodora spp. metacercariae were found in 4 fish species, i.e., T. obscurus, T. trigonocephalus, C. haematocheilus, and A. lactipes, from Gyeongpo-ho. Total 15 C. complanatum metacercariae were detected in 2 (9.1\%) crucian carp, C. auratus, from Songii-ho. The metacercariae of $M$. taiwanensis were found in T. hakonensis from Hyang-ho and Gyeongpo-ho and in P. parva from Gyeongpoho. Total $11 \mathrm{M}$. orientalis metacercariae were detected in 3 (6.3\%) T. hakonensis from Hyang-ho.

\section{Morphologies of unrecorded DTM in Korean fauna}

The metacercariae of Diplostomid No. 1. by Morita (1960) $(\mathrm{n}=10)$ were found in T. hakonensis (from Hwajinpo-ho, Songji-ho and Hyang-ho) and A. flavimanus (Hwajinpo-ho). They were round or elliptical, 195-280 (253) ×180-265 (221) $\mu \mathrm{m}$ in size, have a thin and transparent cyst wall and a yshaped excretory bladder in the posterior portion (Fig. 1A). Body of excysted larvae (415 $\mu \mathrm{m}$ in average length) was divided into 2 parts, fore-body (215 $\mu \mathrm{m}$ long and $345 \mu \mathrm{m}$ wide) transversely expanded and hind-body (200 $\mu \mathrm{m}$ long and 155 $\mu \mathrm{m}$ wide), cylindrical. Oral sucker subterminal, globular, 38 in average diameter. Ventral sucker very small, $13 \mu \mathrm{m}$ in average diameter, located at the posterior portion of fore-body. Preph-

Table 6. Infection status of Metagonimus spp. metacercariae in sea rundace, Tribolodon hakonensis, from coastal lakes in Gangwondo, Korea

\begin{tabular}{lcccr}
\hline \multirow{2}{*}{ Locality } & No. of fish examined & No. (\%) of fish infected & \multicolumn{2}{c}{ No. of metacercariae detected } \\
\cline { 4 - 5 } & & & Range & Average \\
\hline Hwajinpo-ho & 9 & $1(11.1)$ & $1-2$ & 1.0 \\
Songji-ho & 33 & $2(6.1)$ & $1-29$ & 1.5 \\
Mae-ho & 12 & $4(33.3)$ & $1-92$ & 1.0 \\
Hyang-ho & 48 & $14(58.3)$ & $1-38$ & 18.3 \\
Gyeongpo-ho & 24 & $52(41.3)$ & $1-92$ & 10.1 \\
Total & 126 & & 14.6 \\
\hline
\end{tabular}

Table 7. Infection status of $P$. summa metacercariae in mullets from coastal lakes in Gangwon-do, Korea

\begin{tabular}{lcccr}
\hline \multirow{2}{*}{ Locality } & No. of fish examined & No. (\%) of fish infected & \multicolumn{2}{c}{ No. of metacercariae detected } \\
\cline { 4 - 5 } & & $9(69.2)$ & Range & Average \\
\hline Hwajinpo-ho & 13 & $12(100)$ & $2-3,050$ & 672 \\
Songji-ho & 12 & $4(80.0)$ & $32-678$ & 144 \\
Mae-ho & 5 & $2(33.3)$ & $1-3$ & $1-227$ \\
Hyang-ho & 6 & $21(100)$ & $82-918$ & 341 \\
Gyeongpo-ho & 21 & $48(84.2)$ & $1-3,050$ & 316 \\
Total & 57 & & \\
\hline
\end{tabular}



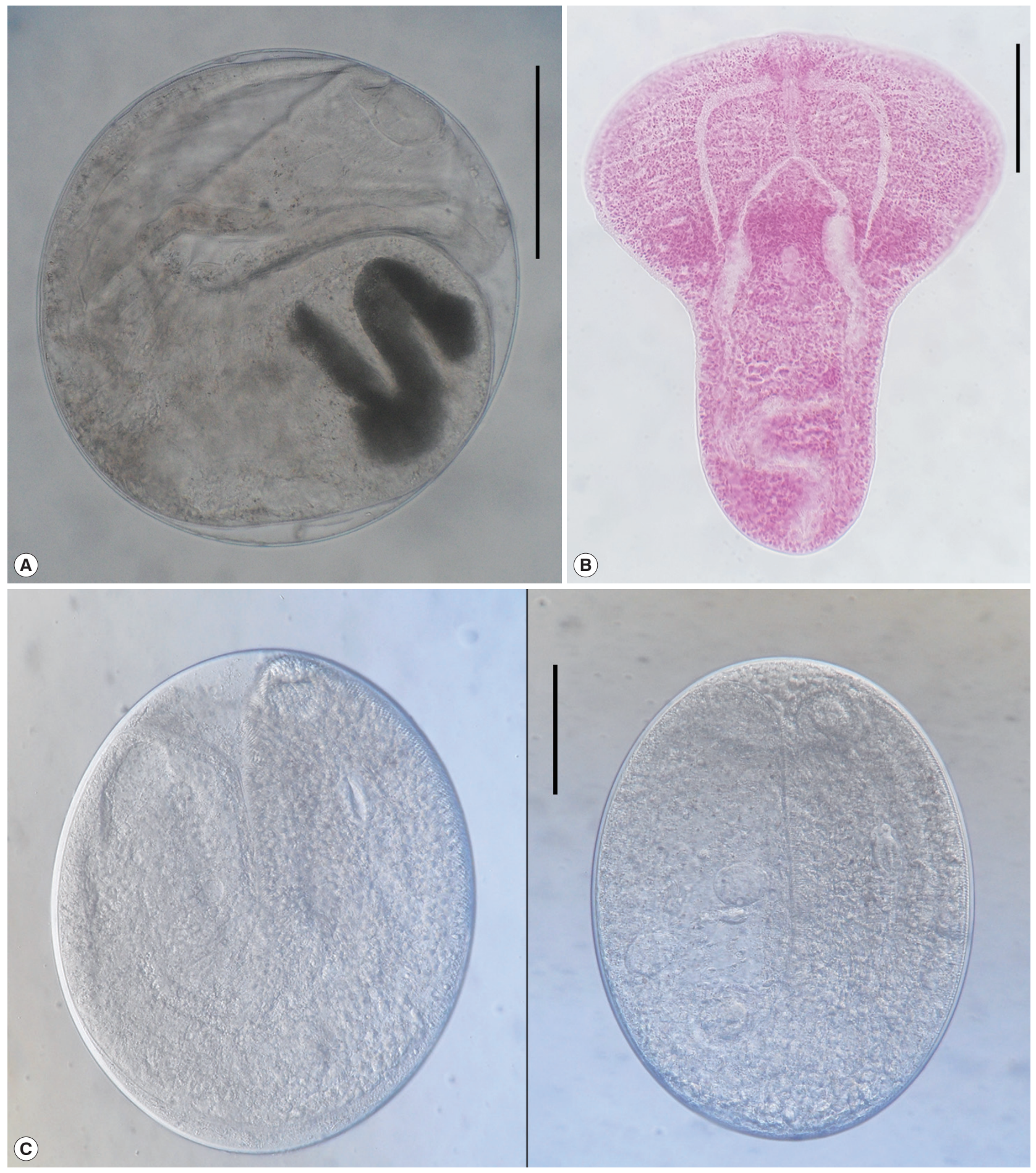

Fig. 1. A metacercaria of Diplostomid No. 1. by Morita (1960): Round or elliptical, $253 \times 221 \mu \mathrm{m}$ in average size, have a thin and transparent cyst wall and a y-shaped excretory bladder in the posterior portion (A). Excysted metacercaria of Diplostomid No. 1. by Morita (1960): Body divided into 2 parts, fore-body ( $215 \mu \mathrm{m}$ long and $345 \mu \mathrm{m}$ wide) and hind-body (200 $\mu \mathrm{m}$ long and $155 \mu \mathrm{m}$ wide). Oral sucker subterminal and globular, ventral sucker very small and located at the posterior portion of fore-body. Prepharynx short, pharnx small, and esophagus relatively short. Ceca bifurcating at the median of fore-body and terminating at the posterior end of body (B). Stictodora sp. metacercariae: Long elliptical, $381 \times 321 \mu \mathrm{m}$ in average size, with a very thin and transparent cyst wall, an elliptical ventrogenital sac and obscure excretory bladder in the posterior portion (C). All scale bar is $100 \mu \mathrm{m}$. 
arynx short, pharynx small, $25 \times 20 \mu \mathrm{m}$ in average size, and esophagus relatively short, $33 \mu \mathrm{m}$ in average length. Ceca bifurcating at the median of fore-body and terminating at the posterior end of body (Fig. 1B).

Stictodora sp. metacercariae $(\mathrm{n}=20)$ were detected in 3 species of goby, i.e., T. obscurus, T. trigonocephalus and A. lactipes, and a species of mullet, C. haematocheilus, from Gyeongpo-ho. They were long elliptical, 325-425 (381)×265-360 (321) $\mu \mathrm{m}$ in size, with a very thin and transparent cyst wall, an elliptical ventrogenital sac and obscure excretory bladder in the posterior portion. Numerous tegumental spines distributed on the anterior half of the body. Oral sucker subterminal, and round. Prepharynx, pharynx and esophagus present. Ventrogenital sac and metraterm armed with leaf-like rodlets in the slight posterior median of the body. Primodia of ovary and testes were seen in the posterior middle of the body (Fig. 1C).

\section{DISCUSSION}

In the present study, we examined total 585 fishes in 18 species, i.e., A. flavimanus, A. lactipes, A. schlegeli, C. auratus, C. haematocheilus, C. carpio, F. gymnauchen, H. nipponensis, G. castaneus, K. punctatus, M. cephalus, P. parva, P. altivelis, S. asotus, T. hakonensis, T. brevispinis, T. obscurus, T. trigonocephalus. Ecologically, most of these fish species (77.8\%) commonly dwell in brackish water and remain 4 ones (22.2\%), i.e., C. auratus, C. carpio, P. parva and $S$. asotus., mainly live in freshwater environment. Total 505 (86.3\%) out of 585 fish examined were ecologically originated from brackish water zone, and remain 80 ones (13.7\%) were freshwater fish. Among fish species examined in this study, sea rundace, T. hakonensis, was most dominant species (21.5\%), and followed by A. flavimanus (13.0\%), C. auratus (11.6\%), K. punctatus (8.7\%), M. cephalus (8.0\%), T. brevispinis (7.5\%), A. lactipes (7.2\%), G. castaneus (7.0\%) and remain 10 fish species (15.5\%) were examined below 15 fish in number. The upper mentioned data for fish ecology suggested that coastal lakes in Gangwon-do are to be the favorable environmental condition for brackish water fish.

About 7 species, i.e., Heterophyes nocens, Acanthotrema felis, Heteropyopsis continua, P. summa, Stellantchasmus falcatus, Stictodora fuscata and S. lari, of zoonotic heterophyid flukes have been prevalent in the brackish water environment in southern and western coastal areas of Korea. And then some species of brackish water fish, i.e., M. cephalus, C. haematocheilus, A. flavimanus, Lateolabrax japonicus and $K$. punctatus, mainly act as the sources of human infection or second intermediate hosts [24]. In the present study, we examined $76 \mathrm{~A}$. flavimanus, $51 \mathrm{~K}$. punctatus, $47 \mathrm{M}$. cephalus, and $10 \mathrm{C}$. haematocheilus, from 5 coastal lakes in Gangwon-do. However, only 2 species, P. sum$m a$ and Stictodora sp., of metacercariae were found. Moreover, P. summa metacercariae were detected in only 2 species of mullet, M. cephalus and C. haematocheilus, but not in yellowfin goby, A. flavimanus, which was already known as the second intermediate host of this heterophyid fluke [25-29]. Stictodora sp. metacercariae were found in 3 species of goby (T. obscurus, T. trigonocephalus and A. lactipes) and a species of mullet ( $C$. haematocheilus) only from Gyeongpo-ho. They were not detected in A. flavimanus and M. cephalus previously reported as the second intermediate host of $S$. lari and $S$. fuscata [30-32]. Meanwhile, 3 species of goby, i.e., T. obscurus, T. trigonocephalus and A. lactipes, are newly added as the second intermediate hosts of Stictodora sp. in this study. The more profound studies on the infections of heterophyid flukes in intermediate and definitive hosts including humans should be conducted in near future in the eastern coastal areas of Korea including Gangwon-do.

More than 10 species, i.e., Metagonimus spp., P. summa, $C$. armatus, C. complanatum, M. orientalis, M. taiwanensis, Echinostoma sp., Stictodora sp., Diplostomum sp. and Diplostomid No. 1. by Morita (1960), of DTM were detected in this study. Among these, Metagonimus spp. metacercariae were mainly found in sea rundace, T. hakonensis, and metacercariae of C. armatus were found in T. hakonensis and T. brevispinis from Hyang-ho, and in A. flavimanus from Gyeongpo-ho. Recently, Sohn et al. [33] broadly investigated the infections with C. armatus metacercariae in fishes from water systems of major rivers in Korea, and they finally listed total 50 fish species (33 genera) as the second intermediate hosts of $C$. armatus in Korea. However, 2 (A. flavimanus and T. brevispinis) out of 3 fish species have not been reported as the second intermediate hosts of $C$. armatus yet in the Korean fauna. Accordingly, total 52 fish species (35 genera) are to be the second intermediate hosts of $C$. armatus in Korea. Two species of Metorchis, M. orientalis and M. taiwanensis, metacercariae were found in 2 species of fish, T. hakonensis and P. parva, from Hyang-ho and Gyeongpo-ho. These trematode metacercariae are commonly detected in the susceptible fish host, $P$. parva, together with Clonorchis sinensis metacercariae in the endemic areas of clonorchiasis in southern regions of Korea [34]. However, C. sinensis metacercariae were not detected at all in this study. The reason why Metorchis 
spp. metacercariae are prevalent even in fish from the non-endemic area of clonorchiasis is to be acted migratory birds as the potent reservoir hosts.

Recently, Sohn et al. [35] surveyed the infection status of Metagonimus spp. metacercariae (MsMc) in fishes from Seomjin-gang and Tamjin-gang. They reported $55.4 \%$ and $57.7 \%$ prevalences, and 96 and $138 \mathrm{MsMc}$ densities in fishes from 2 rivers respectively. In the rasborinid fish from the water systems of Hantan-gang and Imjin-gang, MsMc prevalences were $73.9 \%$ and $72.1 \%$, and MsMc densities were 43 and 19 per fish infected [21]. MsMc were detected in 52 (41.3\%) out of 126 sea rundace, T. hakonensis, examined in this study, and their density was 15 per fish infected. From the findings of previous and present studies, we can suppose that the endemicities with MsMc in fishes from coastal lakes of Gangwondo are much lower than those from Hantangang, Imjin-gang, Seomjin-gang and Tamjin-gang.

Guk et al. [28] investigated on the infection status with $P$. summa metacercariae (PsMc) in mullets from coastal areas in Korea. They reported $87.0 \%, 54.1 \%$, and $4.0 \%$ PsMc prevalences and 177, 47, and 8 PsMc densities in mullet from coastal areas of Yellow Sea, South Sea and East Sea respectively. Recently, Sohn et al. [29] also reported 93.8\%, 69.3\%, and 42.7\% PsMc prevalences, and 496, 369, and 291 PsMc densities in mullets from the coastal areas of upper 3 Seas respectively. From the 2 studies aforementioned, we can know that the endemicity of PsMc in mullet from eastern coastal areas is much lower than those in mullet from southern and western coastal areas of Korea. In regard to the mullet from the eastern coastal areas, PsMc were very rarely detected in the previous studies $[26,28]$. Seo et al. [26] could not found PsMc at all in mullet from Ulsan Metropolitan City, Pohang-si and Yeongdeok-gun, Gyeongsangbuk-do, and Gangneung-si, Gangwon-do. Guk et al. [28] found total 8 PsMc in only one mullet from Donghae-si, Gangwon-do, and they could not detect PsMc at all in mullet from Yeongdeok-gun, Gyeongsangbuk-do, and Sokcho-si, Gangwon-do. In Sohn et al. [29], PsMc were detected in $38(63.3 \%)$ out of 60 mullet from 5 eastern coastal sites, i.e., Ulsan Metropolitan City, Yeongdeokgun, Gyeongsangbuk-do, and Gangneung-si, 2 sites in Goseong-gun, Gangwon-do, but they were not found in 29 mullet from Pohang-si and Uljin-gun, Gyeongsangbuk-do. However, in the present study, P. summa metacercariae (PsMc) were found in $48(84.2 \%)$ out of 57 mullets examined, and their density was 316 per fish infected. Especially, in mullet from 3 coastal lakes, Hwajinpoho, Gyeongpoho and Songjiho, the prevalences were $69.2 \%, 100 \%$, and $100 \%$, and the intensities were 672, 341, and 144 PsMc per fish infected respectively. These interesting findings suggest that the life cycle of P. sum$m a$ is actively maintained in the coastal lakes of Gangwon-do. Accordingly, the residents habitually eat the raw flesh of mullet in these areas should pay attention to the infection of this fluke.

Collectively, it was confirmed that various species of DTM including some species of ZTM are prevalent in fishes from the coastal lakes in Gangwon-do. Although the endemicity of ZTM is not so high in fishes from the surveyed areas, the residents frequently consumed the raw fish dish should pay attention to the infections of zoonotic flukes.

\section{ACKNOWLEDGMENTS}

This study was supported by an Anti-Communicable Diseases Control Program, 2014 (Investigation of fishborne parasites and acquisition of their biological resources in the southern regions of Korea) and 2015 (Investigation of fishborne parasites and acquisition of their biological resources in the eastern regions of Korea) of National Research Institute of Health (NRIH), Korea Centers for Disease Control and Prevention (KCDCP). We thank Jung-A Kim and Hee-Ju Kim, Department of Parasitology and Tropical Medicine, Gyeongsang National University College of Medicine, Jinju, Korea, for their help in fish examinations.

\section{CONFLICT OF INTEREST}

The authors declare no conflict of interest related to this study.

\section{REFERENCES}

1. Gibson DI. Subclass digenea Carus, 1863. In Gibson DI, Jones A, Bray RA eds, Keys to the Trematoda Vol 1. London, UK. CABI Publishing and Natural History Museum. 2001, pp 15-18.

2. Sohn WM. Fish-borne zoonotic trematode metacercariae in the Republic of Korea. Korean J Parasitol 2009; 47 (suppl): 103-113.

3. Sohn WM. Invertebrate Founa of Korea Vol. 6, No. 1. Trematodes. Incheon, Korea. The National Institute of Biological Resources. 2013, pp 1-125.

4. Korea Centers for Disease Control and Prevention. Korea National Institute of Health. National survey of the prevalence of 
intestinal parasitic infections in Korea, 2012. The 8th Report. Osong Chungcheongbuk-do, Korea, 2013.

5. Cho SH, Lee KY, Lee BC, Cho PY, Cheun HI, Hong ST, Sohn WM, Kim TS. Prevalence of clonorchiasis in southern endemic areas of Korea in 2006. Korean J Parasitol 2008; 46: 133-137.

6. Kim HK, Cheun HI, Chung BS, Lee KY, Kim TS, Lee SE, Lee WJ, Cho SH. Prevalence of Clonorchis sinensis infections along the five major rivers in Republic of Korea, 2007. Osong Public Health Res Perspect 2010; 1: 43-49.

7. Jeong YI, Shin HE, Lee SE, Cheun HI, Ju JW, Kim JY, Park MY, Cho SH. Prevalence of Clonorchis sinensis infection among residents along 5 major rivers in the Republic of Korea. Korean J Parasitol 2016; 54: 215-219.

8. Cho SH, Sohn WM, Na BK, Kim TS, Kong Y, Eom KS, Seok WS, Lee T. Prevalence of Clonorchis sinensis metacercariae in freshwater fish from three latitudinal regions of the Korean peninsula. Korean J Parasitol 2011; 49: 385-398.

9. Cho SH, Lee WJ, Kim TS, Seok WS, Lee TJ, Jeong KJ, Na BK, Sohn WM. Prevalence of zoonotic trematode metacercariae in freshwater fish from Gangwon-do, Korea. Korean J Parasitol 2014; 52: 399-412.

10. Sohn WM, Na BK, Cho SH, Park MY, Kim CH, Hwang MA, No KW, Yoon KB, Lim HC. Prevalence of Clonorchis sinensis metacercariae in fish from water systems of Seomjin-gang (River). Korean J Parasitol 2017; 55: 305-312.

11. Sohn WM, Na BK, Cho SH, Ju JW, Son DC. Prevalence and intensity of Clonorchis sinensis metacercariae in freshwater fish from Wicheon Stream in Gunwi-gun, Gyeongsangbuk-do, Korea. Korean J Parasitol 2018; 56: 43-50.

12. Yoon KB, Lim HC, Jeon DY, Park S, Cho SH, Ju JW, Shin SS, Na $\mathrm{BK}$, Sohn WM. Infection status with Clonorchis sinensis metacercariae in fish from Tamjin-gang (River) in Jeollanam-do, Republic of Korea. Korean J Parasitol 2018; 56: 183-188.

13. Chun SK. Studies on some trematodes whose intermediate hosts are fishes in the Naktong river. Bull Fish Coll Pusan Nat Univ (Korea) 1962; 4: 21-38 (in Korean).

14. Lee JT. Studies on the metacercariae from freshwater fishes in the Kum-Ho River. Korean J Parasitol 1968; 6: 77-99.

15. Hwang JT, Choi DW. Changing pattern of infestation with larval trematodes from freshwater fish in river Kumho, Kyungpook Province, Korea. Kyungpook Univ Med J 1980; 21: 460-475.

16. Rhee JK, Lee HI, Baek BK, Kim PG. Survey on encysted cercariae of trematodes from freshwater fishes in Mangyeong riverside area. Korean J Parasitol 1983; 21: 187-192.

17. Rhee JK, Rim MH, Baek BK, Lee HI. Survey on encysted cercariae of trematodes from freshwater fishes in Tongiin riverside areas in Korea. Korean J Parasitol 1984; 22: 190-202.

18. Joo CY. Changing pattern of infection with digenetic larval trematodes from freshwater fish in river Taewha, Kyongnam Province. Korean J Parasitol 1988; 26: 263-274.

19. Kong HH, Choi BR, Moon CH, Choi DW. Larval digenetic trematodes from freshwater fish in river Miryang, Korea. Jpn J Parasitol 1995; 44: 112-1184.
20. Sohn WM, Choi YS. Infection status with trematode metacercariae in the freshwater fish from Chunamchosuchi (pond), Uichang-gun, Kyongsangnam-do, Korea. Korean J Parasitol 1997; 35: 165-170.

21. Sohn WM, Na BK, Cho SH, Lee SW, Choi SB, Seok WS. Trematode metacercariae in freshwater fish from water systems of Hantangang and Imjingang in Republic of Korea. Korean J Parasitol 2015; 53: 289-298

22. Sohn WM, Na BK. Infections with digenetic trematode metacercariae in freshwater fishes from two visiting sites of migratory birds in Gyeongsangnam-do, Republic of Korea. Korean J Parasitol 2019; 57: 273-281.

23. Komiya Y. Metacercariae in Japan and adjacent territories. In Morishita K, Komiya Y, Matsubayashi H eds. Progress of Medical Parasitology in Japan Vol 2. Tokyo, Japan. Meguro Parasitological Museum, 1965, pp 197-198.

24. Chai JY. Iintestinal flukes. In Murrell DK, Fried B eds, FoodBorne Parasitic Zoonoses: Fish and plant-borne parasites. World class parasites, Vol 11. New York, USA. Springer. 2007, pp 53-115

25. Chun SK. A study on some trematodes whose intermediate host are brackish water fish. (II) The life history of Pygidiopsis summa, the intermediate host of which is Mugil cephalus. Bull Fish Coll Pusan Nat Univ (Korea) 1963; 5: 1-5 (in Korean).

26. Seo BS, Hong ST, Chai JY, Cho SY. Studies on intestinal trematodes in Korea IV. Geographical distribution of Pygidiopsis and Heterophyes metacercariae. Seoul J Med 1981; 22: 236-242.

27. Kim DG, Kim TS, Cho SH, Song HJ, Sohn WM. Heterophyid metacercarial infections in brackish water fishes from Jinju-man (Bay), Kyongsangnam-do, Korea. Korean J Parasitol 2006; 44: 7-13.

28. Guk SM, Shin EH, Kim JL, Sohn WM, Hong KS, Yoon CH, Lee $\mathrm{SH}, \mathrm{Rim} \mathrm{HJ}$, Chai JY. A survey of Heterophyes nocens and Pygidiopsis summa metacercariae in mullets and gobies along the coastal areas of the Republic of Korea. Korean J Parasitol 2007; 45: 205211.

29. Sohn WM, Na BK, Cho SH, Lee WJ, Park MY, Lee SW, Choi SB, Huh BN, Seok WS. Pygidiopsis summa (Digenea: Heterophyidae): Status of metacercarial infection in mullets from coastal areas in the Republic of Korea. Korean J Parasitol 2016; 54: 497-502.

30. Chai JY, Park SK, Hong SJ, Choi MH, Lee SH. Identification of Stictodora lari (Heterophyidae) metacercariae encysted in the brackish water fish, Acanthogobius flavimanus. Korean J Parasitol 1989; 27: 253-259.

31. Sohn WM, Chai JY, Lee SH. Stictodora fuscatum (Heterophyidae) metacercariae encysted in gobies, Acanthogobius flavimanus. Korean J Parasitol 1994; 32: 143-148.

32. Cho SH, Kim IS, Hwang EJ, Kim TS, Na BK, Sohn WM. Infection status of estuarine fish and oysters with intestinal fluke metacercariae in Muan-gun, Jeollanam-do, Korea. Korean J Parasitol 2012; 50: 215-220.

33. Sohn WM, Na BK, Cho SH, Ju JW, Kim CH, Yoon KB, Kim JD, Son DC, Lee SW. Infections with Centrocestus armatus metacercariae in fishes from water systems of major rivers in Republic of 
Korea. Korean J Parasitol 2018; 56: 341-349.

34. Sohn WM. Infection status of Pseudorasbora parva from the Sunam stream with metacercariae of Metorchis orientalis. Korean J Parasitol 1991; 29: 311-313 (in Korean).
35. Sohn WM, Na BK, Cho SH, Ju JW, Kim CH, Yoon KB. Infection status with Metagonimus spp. metacercariae in fishes from Seomjin-gang and Tamjin-gang in Republic of Korea. Korean J Parasitol 2018; 56: 351-358. 